\title{
Sistem Informasi Geografis Pemetaan Aset Daerah Menggunakan Algoritma Djikstra Di BKD Kota Cirebon
}

\author{
Aab Abdus Salam ${ }^{1}$, Fahmi*2 \\ ${ }^{1,2}$ Teknik Informatika, STIKOM Poltek Cirebon, Indonesia \\ e-mail correspondence: ${ }^{2}$ fahmionly@gmail.com
}

\begin{abstract}
Abstrak
Sistem otonomi daerah yang baru mewajibkan pemerintah daerah untuk mengelola aset-aset yang dimiliki oleh masing-masing daerah tersebut. Dalam hal ini pengelolaan aset meliputi pencatatan, pembukuan, pelaporan, pengarsipan dan penghapusan aset. Salah satu faktor penghambat dalam pengelolaan aset daerah yang ada di Kota Cirebon yaitu kurangnya informasi mengenai lokasi aset yang ada di Kota Cirebon, karena data yang disajikan masih belum memiliki data spasial (keruangan) yang berisi titik-titik koordinat suatu aset daerah (fasilitas sosial dan fasilitas umum). Sistem informasi geografis dibangun dengan tujuan dapat memenuhi keperluan informasi yang cepat, lengkap dan tepat sehingga dapat mempermudah pemerintah daerah dalam pengelolaan aset yang dimilikinya. SIG ini dapat memberikan datadata berupa data spasial beserta dengan atribut-atributnya dalam bentuk geografis yang ditampilkan dalam peta digital dengan bantuan Google MAPS API (Application Programming Interface) dari Google yang mampu memetakan aset-aset daerah beserta rute untuk menuju ke aset tersebut, sehingga informasi yang diperoleh menjadi dinamis dan lebih menarik serta lebih mudah untuk dipahami.
\end{abstract}

Kata kunci-SIG, Algorithme Dijkstra, fasilitas sosial dan fasilitas umum, BKD Kota Cirebon

\begin{abstract}
The new regional autonomy system requires local governments to manage the assets owned by each of these areas. In this case asset management includes recording, bookkeeping, reporting, filing and asset deletion. One of the inhibiting factors in the management of existing assets in Cirebon City is the lack of information on the location of existing assets in the city of Cirebon, because the data presented still do not have spatial data (spatial) which contains the coordinate points of a regional asset (social facilities and public facilities). Geographic information system is built with the aim to meet the needs of information quickly, complete and appropriate so as to facilitate local governments in the management of assets owned. This GIS can provide data in the form of spatial data along with its attributes in geographic form displayed in digital maps with the help of Google MAPS API (Application Programming Interface) from Google that is able to map the assets of the region along the route to get to the asset, so that the information obtained becomes dynamic and more interesting and easier to understand
\end{abstract}

Keywords-GIS, Dijkstra Algorithm, social facilities and public facilities, BKD Kota Cirebon

\section{PENDAHULUAN}

Sistem otonomi daerah yang baru mewajibkan pemerintah daerah untuk mengelola asetaset yang dimiliki oleh masing-masing daerah tersebut. Salah satu aset daerah yang perlu dikelola dengan baik yaitu fasilitas sosial dan fasilitas umum yang ada di suatu daerah tertentu, informasi mengenai fasilitas sosial dan fasilitas umum tidak hanya dalam bentuk data nonspasial saja melainkan memerlukan data tambahan berupa atribut spasial (data keruangan)

Submitted: 20 April 2019, Accepted: 29 April 2019, Published: Mei 2019

ISSN: 2685-4902 (online), Website: http://jurnal.umus.ac.id/index.php/intech 
sehingga lokasi dari aset tersebut dapat tergambarkan semuanya di dalam sebuah peta konvensional maupun peta digital. Dengan adanya visualisasi ini diharapkan pemerintah daerah dapat menggali atau mengolah informasi lebih dalam sehingga mendapatkan gambaran terkait pola data spasial yang berhubungan dengan pengelolaan aset daerahnya.

Informasi mengenai aset darah yang dimiliki pemerintah daerah harusnya tidak hanya dapat dimanfaatkan oleh Badan Keuangan Daerah (BKD) saja, melainkan dapat dimanfaatkan juga oleh Sekretaris Daerah serta Anggota Dewan sesuai dengan kebutuhannya. Namun bila informasi tersebut hanya dituangkan dalam bentuk peta konvensional saja maka akan terasa tidak efisien dalam hal manajemen waktu dan biaya karena peta konvensional tidak mampu memberikan informasi secara lengkap dan paling baru mengenai lokasi aset daerah. Oleh karena itu dibutuhkan sebuah sistem yang mampu mengatasi masalah - masalah ini yaitu Sistem Informasi Geografis (SIG).

Sistem informasi geografis dibangun dengan tujuan dapat memenuhi keperluan informasi yang cepat, lengkap dan tepat sehingga dapat mempermudah pemerintah daerah dalam pengelolaan aset yang dimilikinya. SIG ini dapat memberikan data-data berupa data spasial beserta dengan atribut-atributnya dalam bentuk geografis yang ditampilkan dalam peta digital dengan bantuan Google MAPS API (Application Programming Interface) dari Google yang mampu memetakan aset-aset daerah beserta rute untuk menuju ke aset tersebut, sehingga informasi yang diperoleh menjadi dinamis dan lebih menarik serta lebih mudah untuk dipahami.

1. Berdasarkan permasalahan tersebut, maka beberapa permasalahan yang dapat diidentifikasi yaitu: Sistem yang ada masih manual dalam memetakan aset daerah di Kota Cirebon.

2. Pemetaan lokasi aset masih menggunakan peta konvensional.

3. Aset daerah belum di kelola dengan maksimal, hal ini akibat kurangnya informasi mengenai lokasi aset daerah di Kota Cirebon.

Dalam merancang sebuah sistem diperlukan pembatasan masalah, hal ini bertujuan untuk mengetahui ruang lingkup permasalahan yang ada sehingga pembuatan sistem informasi geografis menjadi lebih mudah. Adapun batasan-batasan tersebut adalah sebagai berikut:

1. Pemetaan aset daerah pada sistem informasi geografis yang akan dibangun berupa fasilitas sosial dan fasilitas umum.

2. Penentuan rute menuju lokasi aset menggunakan algoritme dijkstra.

3. Sistem yang akan dibuat hanya memetakan aset daerah berupa fasilitas sosial dan fasilitas umum di wilayah Perum Perumnas cabang Cirebon IV (empat) Kota Cirebon yang dikelola oleh bidang Barang Milik Daerah (BMD) di Badan Keuangan Daerah (BKD) Kota Cirebon.

4. Aplikasi yang akan dibuat berbasis web dan hanya bisa diakses dengan koneksi internet.

Sedangkan tujuan dilakukannya penelitian ini adalah sebagai berikut:

1. Untuk mengetahui pemetaan fasilitas sosial dan fasilitas umum pada bidang Barang Milik Daerah (BMD) di Badan Keuangan Daerah (BKD) Kota Cirebon.

2. Untuk mengetahui kendala-kendala dalam pemetaan fasilitas sosial dan fasilitas umum Kota Cirebon.

3. Untuk membangun sistem baru terkait pengelolaan fasilitas sosial dan fasilitas umum pada bidang Barang Milik Daerah (BMD) di Badan Keuangan Daerah (BKD) Kota Cirebon.

4. Untuk menerapkan sistem informasi geografis beserta dengan pencarian rute terdekat menggunakan algoritma dijkstra.

Sebagai bahan perbandingan dan referensi, maka penulis melakukan beberapa tinjauan pustaka terhadap beberapa jurnal ilmiah yang berkaitan. Pada penelitian [1] permasalahan yang dibahas yaitu mengenai: bagaimana menentukan lintasan terpendek antar kota karena terdapat jalan yang bercabang-cabang? Serta bagaimana merancang dan menerapkan algoritme dijkstra untuk melakukan kalkulasi terhadap semua kemungkinan bobot terkecil dari setiap titik. Solusi yang penulis tawarkan yaitu dengan membuat sebuah aplikasi yang dapat mencari jalan terdekat menuju sebuah wilayah. Adapun aplikasi yang dibuat yaitu dengan menggunakan bahasa 
pemrograman Delphi 7, serta software pendukung seperti Corel draw 12 dan Microsoft acces 2007 sebagai databasenya serta tidak ketinggalan pula algoritme Dijkstra sebagai algoritme untuk mencari jalur/jarak terdekat. Manfaat dari aplikasi ini yaitu dengan menerapkan algoritme Dijkstra untuk mencari lintasan terpendek dapat membantu para pengguna jalan, traveling salesman, perusahaan yang bergerak di bidang pariwisata dan angkutan antar provinsi, instansi pemerintah dan lain sebagainya terutama bagi yang membutuhkan informasi tentang lintasan terdekat.

Sedangkan pada penelitian [2], penulis menemukan masalah yaitu diperlukan sebuah sistem informasi yang dapat memetakan fasilitas umum dan sosial, dengan adanya pemetaan lokasi mengenai fasilitas umum dan sosial, maka informasi yang didapat akan lebih akurat dan up to date. Selain itu, melalui pemetaan pengambilan keputusan untuk mendirikan fasilitas umum dan sosial baru dapat dilakukan dengan mudah dan cepat. Untuk dapat merealisasikan sistem ini maka penulis membangun sebuah sistem informasi geografis pemetaan fasilitas umum dan sosial yang dibangun dengan bahasa pemrograman PHP dan Mapserver untuk pembuatan peta dan mengolah data spasialnya, kemudian menggunakan MySQL spasial untuk menampung data-data spasial sepeti line, polygon, layer, data raster dan sebagainya. Target pengguna dari aplikasi ini yaitu Dinas Tata Ruang Bangunan dan Perumahan (DTRB) Kabupaten Serang, setelah aplikasi ini dibangun diharapkan dapat menyelesaikan permasalahan diatas dan dapat membantu pejabat berwenang di dinas tersebut untuk mengelola tata ruang mengenai pembangunan fasilitas umum dan sosial. Pada tahap uji coba aplikasi ini berjalan dengan baik dan dapat menampilkan pemetaan fasilitas umum dan sosial di Kabupaten Serang.

Penelitian [3] membahas permasalahan yang ada pada Bappeda kabupaten sumedang mengenai pemetaan fasilitas umum yang dimilikinya. Menurutnya Bappeda adalah badan atau lembaga teknis yang mempunyai tugas pokok membantu bupati dalam penyelenggaraan pemerintahan daerah di bidang penelitian dan perencanaan pembangunan daerah termasuk di dalamnya pemetaan fasilitas umum. Pengelolaan data fasilitas umum di sana belum berbasis database sehingga pengelolaan data bersifat statis, kurang terpusat, dan data tersebar dalam dokumen-dokumen terpisah. Data fasilitas umum juga belum memiliki koordinat geografi sehingga lokasi-lokasinya tidak bisa diketahui dengan pasti. Akibatnya pemantauan dan perencanaan pembangunan tidak bisa dilakukan secara maksimal. Sistem informasi geografis menjadi solusi dalam permasalahan ini, karena sistem informasi geografis merupakan suatu sistem yang mengandung data atribut dan data spasial dalam basis datanya. Metode yang digunakan dalam proses pembangunan sistem informasi geografis pemetaan fasilitas umum di Kabupaten Sumedang ini mengadopsi model waterfall. Pendekatan analisis menggunakan metode analisis terstruktur. Bahasa pemrograman yang digunakan dalam penelitian ini adalah PHP dengan database MySQL. Sedangkan untuk pemetaan fasilitas umum diimplementasikan dengan Google Maps API.

Algoritma djikstra juga dapat digunakan untuk melakukan pencarian rute terpendek menuju indekos. Penelitian tersebut menghasilkan sebuah aplikasi android yang menerapkan algoritma dijkstra dalam menghasilkan sebuah pencarian jarak terpendek menuju Indekos. Pengujian yang dilakukan menggunakan pengujian Black Box terhadap 10 kelas uji dan 33 skenario pengujian yang diujikan dengan 33 skenario uji berhasil $100 \%$ berjalan dengan sebagaimana mestinya dan ada 30 pengujian sistem ditempat berbeda yang valid. Pengujian kelayakan sistem dilakukan pada responden mahasiswa Universitas Bengkulu. (3) Hasil pengujian menunjukan bahwa variabel tampilan dengan kategori sangat baik $(3,31 \%)$, variabel kinerja sistem dengan kategori sangat baik $(3.1875 \%)$ dan variabel kemudahan pengguna dengan kategori sangat baik $(3,125 \%)$ sehingga secara keseluruhan disimpulkan bahwa aplikasi termasuk dalam kategori sangat baik (Skor 3,2075 dari Skala 4,00).[5]

Penelitian ini bertempat di Surabaya Pusat yang terdiri dari Kecamatan Genteng, Tegalsari, Bubutan dan Simokerto dan bertujuan untuk melakukan pemetaan terhadap aset bangunan milik Pemkot Surabaya, membangun Sistem Informasi Geografis (SIG), mengevaluasi aspek legal aset bangunan milik Pemkot Surabaya. Kegiatan ini menggunakan data dari Dinas Pengelolaan Bangunan dan Tanah, Dinas Pendidikan dan Dinas Kesehatan 
maupun hasil pengambilan data di lapangan. Dengan menggunakan SIG, evaluasi aspek legal ditemukanaset bangunan milik Pemkot Surabaya di Surabaya Pusat yang belum memiliki serifikat sebanyak $70,22 \%$ dan hanya sekitar $29,78 \%$ aset bangunan yang telah memiliki sertifikat[7]

\section{METODE PENELITIAN}

\subsection{Pengembangan perangkat lunak}

Penelitian dan pengembangan (research and development-R\&D) berasal dari dua kata yaitu penelitian (research) dan pengembangan (development). Frase ini merupakan gabungan 2 (dua) kata kerja yang memiliki tujuan aktivitas. Penelitian (research) merupakan suatu mekanisme atau kegiatan ilmiah dengan mengikuti aturanaturan atau norma-norma penelitian yang sudah standar dan diakui secara universal; sedangkan pengembangan (development) berarti suatu aktivitas yang merujuk pada penambahan, peningkatan, baik dari segi kuantitas maupun kualitas dari suatu kegiatan atau objek yang menjadi kegiatan.[8]

Pada penelitian ini, penulis melakukan suatu penelitian dengan metode penelitian yang digunakan adalah metode penelitian dan pengembangan (Research and Development). Alasan penulis menggunakan metode penelitian R\&D (Research and Development) yaitu karena penelitian yang dilakukan penulis akan menghasilkan sebuah produk aplikasi sistem informasi geografis, dengan kata lain hasil media pada penelitian ini merupakan hasil pengembangan karena menghasilkan sebuah produk baru.

Setelah penulis melakukan pengamatan di lokus penelitian yang berkaitan dengan kegiatan pemetaan fasilitas sosial dan fasilitas umum di Badan Keuangan Daerah (BKD) Kota Cirebon terdapat beberapa kekurangan dalam proses tersebut sehingga perlu dilakukan beberapa perubahan pada sistem yang sedang berjalan sehingga sistem tersebut dapat berjalan dengan baik.

\subsection{Desain prosedur perangkat lunak}

Pada desain prosedur pemetaan, penulis akan menggambarkan proses perjalanan dari data input (masukan) menjadi data output (keluaran). Adapun proses pemetaan fasilitas sosial dan fasilitas umum adalah sebagai berikut:

1. Pihak developer (pengembang) dari Perumnas cabang Cirebon IV memberikan dokumen berisi daftar fasilitas sosial dan fasilitas umum.

2. Kepala bidang BMD memeriksa data tersebut dan menyerahkan ke Sub bidang pembukuan dan pelaporan barang milik daerah melakukan pencatatan aset daerah berupa aset gedung dan bangunan.

3. Staff administrasi dan outsourcing melakukan pengecekan ke lapangan berdasarkan data yang telah diterima sebelumnya, yang di dampingi oleh BPN Kota Cirebon untuk pengukuran data meliputi panjang, lebar, luas dan titik koordinat garis lintang dan garis bujur (latitude dan longitude) fasilitas sosial dan fasilitas umum.

4. Setelah data tersebut sudah di validasi keabsahan datanya maka langkah selanjutnya staff administrasi dari sub bidang pembukuan dan pelaporan melakukan penginputan data ke dalam database dengan cara mengakses alamat website localhost/assetbkd, domain ini akan berbeda setelah website tersebut diunggah ke hosting.

5. Setelah website terbuka maka langkah selanjutnya yaitu melakukan proses Login dengan akun yang telah dibuat sebelumnya yang berlevel administrator. Setelah berhasil login akan terlihat beberapa navigasi menu yang ada di sebelah kiri halaman website.

6. Kemudian user (pengguna) menginput data dengan cara meng-klik menu data fasilitas sosial dan fasilitas umum, lalu menekan tombol Tambah Data sehingga sehingga akan muncul form isian untuk mengisi data sesuai dengan kolom isian yang sudah disediakan.

7. Setelah yakin bahwa data yang di-input sudah benar maka user meng-klik tombol Simpan untuk menyimpan data. Jika ada perubahan data maka dapat diperbaharui dengan cara memilih data yang akan di ubah kemudian klik tombol Edit, lalu akan muncul form isian 
dengan isi data yang akan diperbaharui selanjutnya lakukan edit data, jika sudah selesai klik tombol Update untuk menyimpan kembali data tersebut.

\subsection{Algoritma djikstra}

Shortest path adalah pencarian rute terpendek antara titik yang ada pada graf G. masalah lintasan terpendek adalah bagaimana kita mencari sebuah jalur pada graf yang meminimumkan jumlah bobot edge pembentuk jalur tersebut. Algoritma Dijkstra adalah salah satu metode untuk memecahkan masalah pencarian rute terpendek.[9]

Dalam penelitian ini peneliti membangun sebuah sistem informasi yang dapat memetakan fasilitas umum dan sosial beseta pengurutannya dengan menggunakan algoritme dijkstra sebagai algoritme dasar dalam mencari lintasan terpendek ke sebuah fasilitas umum maupun sosial.

Algoritma yang ditemukan oleh Dijkstra untuk mencari path terpendek merupakan algoritme yang lebih efisien dibandingkan algoritme Warshall, meskipun implementasinya juga lebih sukar. Misalkan $G$ adalah graf berarah berlabel dengan titik-titik $V(G)=\left\{V_{1}, V_{2}, \ldots V_{n}\right\}$ dan path terpendek yang dicari adalah dari v1 ke vn. Algoritme dijkstra dimulai dari titik v1. Dalam iterasinya, algoritme akan mencari satu titik yang jumlah bobotnya dari titik 1 terkecil. Titik-titik yang terpilih dipisahkan dan titik-titik tersebut tidak diperhatikan lagi dalam iterasi berikutnya[1].

Misalkan :

Dimana:

$$
\mathrm{V}(\mathrm{G})=\left\{\mathrm{v}_{1}, \mathrm{v}_{2}, \ldots, \mathrm{v}_{\mathrm{n}}\right\}
$$

L $\quad$ : Himpunan titik-titik $\varepsilon \mathrm{V}(\mathrm{G})$ yang sudah terpilih dalam jalur path terpendek.

$\mathrm{D}(\mathrm{j}) \quad$ : Jumlah bobot path terkecil dari $\mathrm{v}_{1} \mathrm{ke} \mathrm{v}_{\mathrm{j}}$.

$\mathrm{W}(\mathrm{i}, \mathrm{j}) \quad$ : Bobot garis dari titik $\mathrm{v}_{\mathrm{i}} \mathrm{ke} \mathrm{v}_{\mathrm{j}}$.

$\mathrm{W}^{*}(1, \mathrm{j})$ : Jumlah bobot path terkecil dari $\mathrm{v}_{1} \mathrm{ke}_{\mathrm{j}}$.

Secara formal, algoritme dijkstra untuk mencari path terpendek adalah sebagai berikut :

1. $L=\{\}$;

$\mathrm{V}=\left\{\mathrm{v}_{2}, \mathrm{v}_{3}, \ldots, \mathrm{v}_{\mathrm{n}}\right\}$

2. Untuk $\mathrm{i}=2, \ldots ., \mathrm{n}$, lakukan $\mathrm{D}(\mathrm{i})-\mathrm{w}(1, \mathrm{i})$

3. Selama $\mathrm{v}_{\mathrm{n}} \notin$ lakukan :

a. Pilih titik $\mathrm{v}_{\mathrm{k}} \in \mathrm{V}$ - $\mathrm{L}$ dengan $\mathrm{D}(\mathrm{k})$ terkecil. $\mathrm{L}=\mathrm{L} \mathrm{U}\left\{\mathrm{v}_{\mathrm{k}}\right\}$.

b. Untuk setiap $v_{j} \in V-L$ lakukan : Jika $D(j)>D(k)+W(k, j)$ maka ganti $D(j)$ dengan $\mathrm{D}(\mathrm{k})+\mathrm{W}(\mathrm{k}, \mathrm{j})$

4. Untuk setiap $v_{j} \in V, w^{*}(1, j)=D(j)$.

Menurut algoritme di atas, path terpendek dari titik $\mathrm{v}_{1}$ ke $\mathrm{v}_{\mathrm{n}}$ adalah melalui titik-titik dalam L secara berurutan, dan jumlah bobot path terkecilnya adalah $\mathrm{D}(\mathrm{n})$.

Misalkan diberi graf berbobot seperti dibawah :

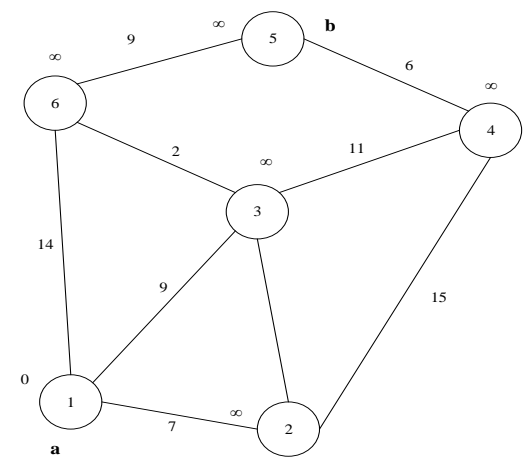

Gambar 1 Contoh menemukan jalur menggunakan algoritme Dijkstra [4] 
Pertama-tama tentukan titik mana yang akan menjadi node awal, lalu beri beri bobot jarak pada node pertama ke node terdekat satu persatu, algoritme dijkstra akan melakukan pengembangan pencarian dari satu titik ke titik lain dan ke titik selanjutnya tahap demi tahap. Urutan logika dari algoritme dijkstra sebagai berikut:

1. Beri nilai bobot (jarak) untuk setiap titik ke titik lainnya, lalu set nilai 0 pada node awal dan tak hingga terhadap node lain (belum terisi).

2. Set semua node belum terjamah dan set node awal sebagai node keberangkatan.

3. Dari node keberangkatan, pertimbangkan node tetangga yang belum terjamah dan hitung jaraknya dari titik keberangkatan. Sebagai contoh, jika titik keberangkatan A ke B memiliki bobot jarak 6 dan dari B ke node $\mathrm{C}$ berjarak 2, maka jarak ke $\mathrm{C}$ melewati B menjadi $6+2=8$. Jika jarak ini lebih kecil dari jarak sebelumnya (yang telah terekan sebelumnya) hapus data lama, simpan ulang data jarak dengan jarak yang baru.

4. Saat kita selesai mempertimbangkan setiap jarak terhadap node tetangga, tandai node yang telah terjamah sebagai node terjamah. Node terjamah tidak akan pernah di cek kembali, jarak yang disimpan adalah jarak terakhir dan yang paling minimal bobotnya.

5. Set node belum terjamah dengan jarak terkecil (dari node keberangkatan) sebagai node keberangkatan selanjutnya dan lanjutkan dengan kembali ke step 3.

\section{HASIL DAN PEMBAHASAN}

Desain yang digunakan penulis dalam mendeskripsikan sistem yang baru adalah menggunakan UML (Unified Modeling Language), karena UML dapat menjabarkan setiap detail bagian dari sistem yang sedang dibangun. Selain itu UML merupakan metodologi dalam mengembangkan sistem berorientasi objek dan juga merupakan alat untuk mendukung pengembangan system[10].Gambaran mengenai usecase diagram pada sistem yang dibuat terangkum pada Gambar 2. Berdasarkan Gambar 2, maka penulis dapat menggambarkan spesifikasi usecase diagram terhadap aktor dan usecase yang dibuat. Rangkuman spesifikasi terdapat pada Tabel 1.

Tabel 1. Spesifikasi usecase diagram

\begin{tabular}{|c|c|c|c|}
\hline No. & Aktor & $\begin{array}{l}\text { Nama use } \\
\quad \text { case }\end{array}$ & Deskripsi \\
\hline \multirow[t]{10}{*}{1.} & \multirow{10}{*}{ Admin } & Lihat peta & $\begin{array}{l}\text { Merupakan use case generalisasi dari } \\
\text { use case data lokasi }\end{array}$ \\
\hline & & Lihat data & $\begin{array}{l}\text { Merupakan use case generalisasi dari } \\
\text { use case data fasos fasum }\end{array}$ \\
\hline & & Get route & $\begin{array}{l}\text { Merupakan use case generalisasi dari } \\
\text { use case data lokasi }\end{array}$ \\
\hline & & $\begin{array}{l}\text { Cek user dan } \\
\text { password }\end{array}$ & $\begin{array}{l}\text { Merupakan use case turunan dari use } \\
\text { case login }\end{array}$ \\
\hline & & Login & $\begin{array}{l}\text { Use case yang berfungsi untuk } \\
\text { mengolah proses login }\end{array}$ \\
\hline & & $\begin{array}{l}\text { Data fasos } \\
\text { fasum }\end{array}$ & $\begin{array}{l}\text { Use case untuk mengolah data fasos } \\
\text { fasum meliputi input, proses dan } \\
\text { output }\end{array}$ \\
\hline & & Data lokasi & $\begin{array}{l}\text { Use case untuk mengolah data-data } \\
\text { spasial. }\end{array}$ \\
\hline & & Data admin & $\begin{array}{l}\text { use case untuk mengolah informasi } \\
\text { akun administrator }\end{array}$ \\
\hline & & Kelola data & $\begin{array}{l}\text { Merupakan use case generalisasi dari } \\
\text { use case data fasos fasum }\end{array}$ \\
\hline & & $\begin{array}{c}\text { Kelola } \\
\text { peta/lokasi }\end{array}$ & $\begin{array}{l}\text { Merupakan use case generalisasi dari } \\
\text { use case data lokasi }\end{array}$ \\
\hline
\end{tabular}




\begin{tabular}{|c|c|c|l|}
\hline No. & Aktor & $\begin{array}{c}\text { Nama } \text { use } \\
\text { case }\end{array}$ & \multicolumn{1}{c|}{ Deskripsi } \\
\hline & & $\begin{array}{c}\text { Kelola data } \\
\text { admin }\end{array}$ & $\begin{array}{l}\text { Merupakan use case generalisasi dari } \\
\text { use case data admin }\end{array}$ \\
\hline
\end{tabular}

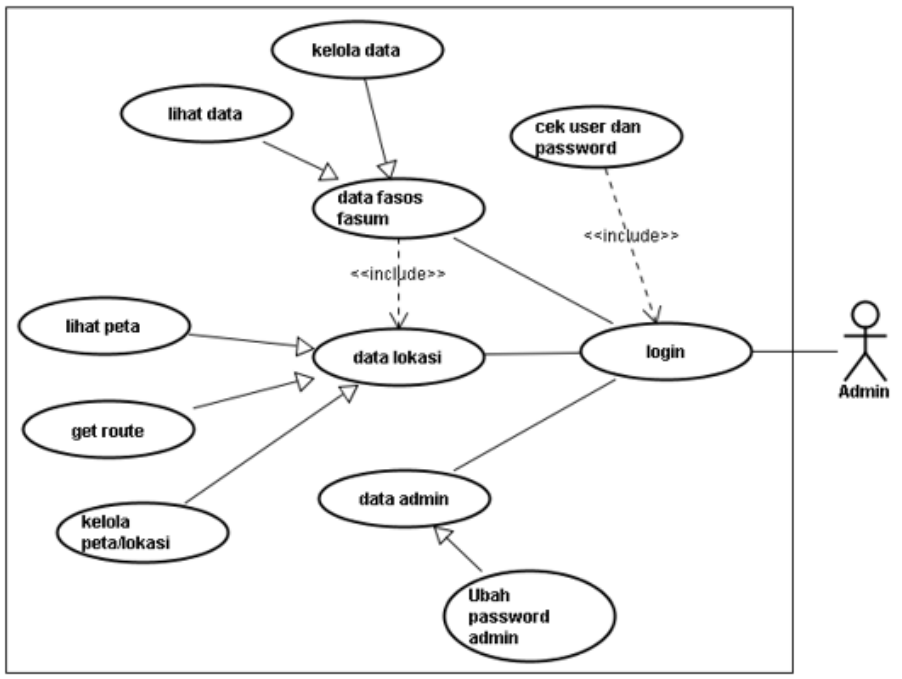

Gambar 2. Usecase diagram

Penulis menggunakan activity diagram untuk menjabarkan proses dari masing-masing menu yang ada pada sistem baru. Gambar 3 sampai Gambar 5 menjelaskan mengenai activity diagram menu data fasos fasum, activity diagram menu peta, dan activity diagram menu rute.

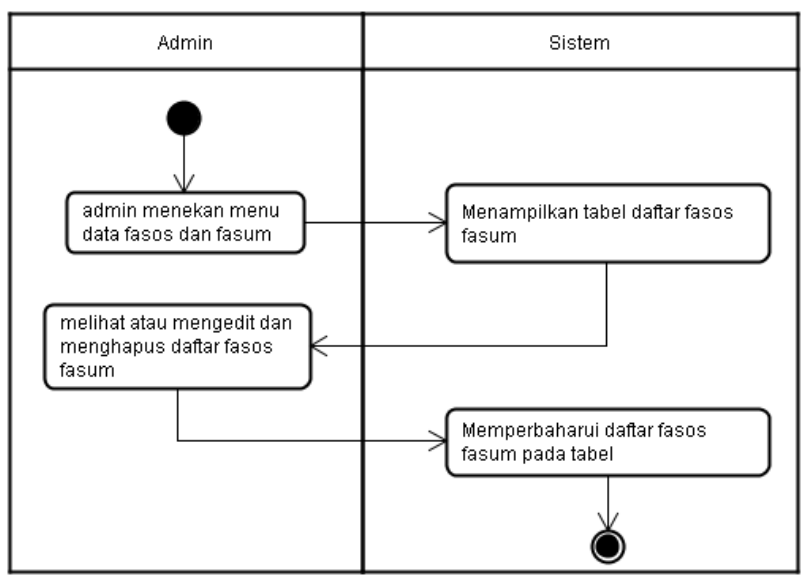

Gambar 3. activity diagram menu data fasos fasum

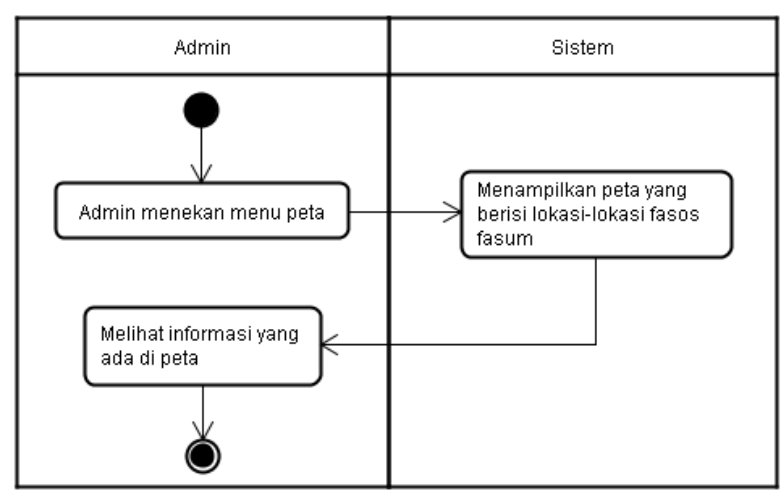


Gambar 4. activity diagram menu peta

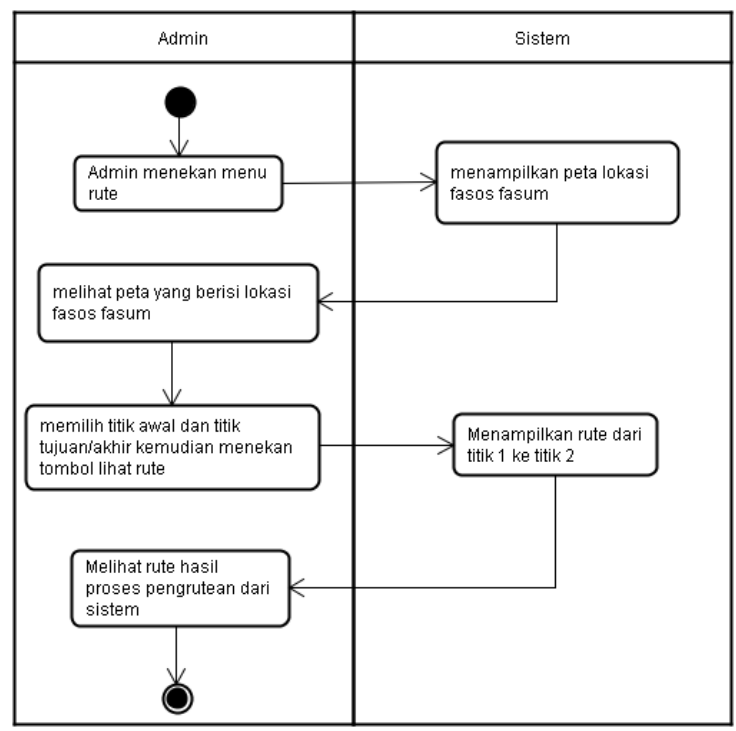

Gambar 5. activity diagram menu rute

Sedangkan Gambar 6 menjelaskan mengenai squance diagram pemetaan fasos dan fasum yang dilakukan.

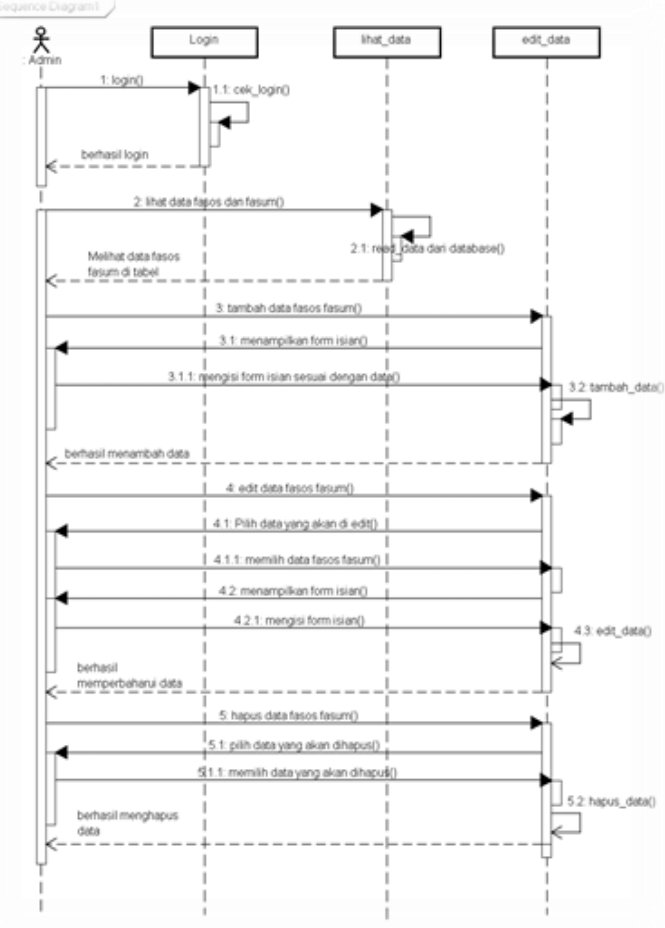

\section{Gambar 6. Squance diagram pemetaan fasos fasum}

Berdasarkan perancangan diatas, maka tampilan menu utama untu aplikasi yang dibuat terdapat pada Gambar 7. 


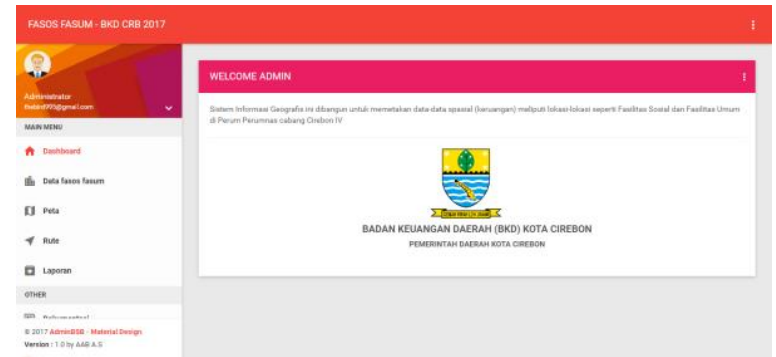

Gambar 7. Menu utama aplikasi

Pada bagian kiri Gambar 7, terdapat beberapa menu seperti data fasos fasum, peta, rute, laporan, dokumentasi dan menu tentang.

Pada menu data fasos fasum, admin dapat melakukan pengolahan data fasos fasum seperti menambah data, mengedit, dan menghapus data. Selain itu admin pun dapat melihat fasilitas sosial dan fasilitas umum pada peta dengan memilih menu Peta. Tempilan menu peta terlilhat pada gambar 8 .

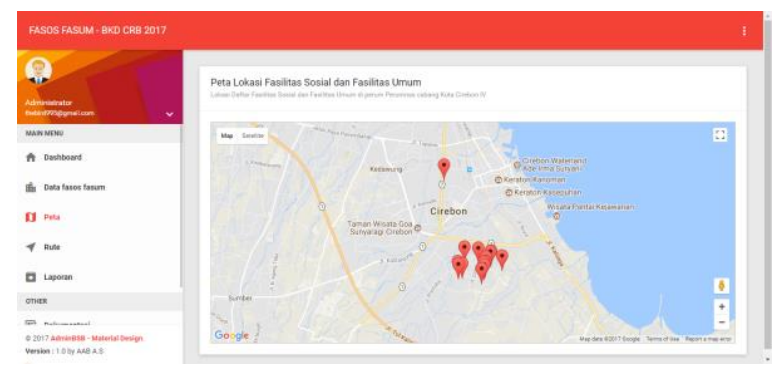

Gambar 8. Menu peta

Untuk melihat rute menuju fasilitas-fasilitas, terdapat pada menu rute dengan memasukkan titik awal dan titik akhir lokasi yang akan dilihat rutenya. Gambar 9 adalah tampilan untuk menu rute.

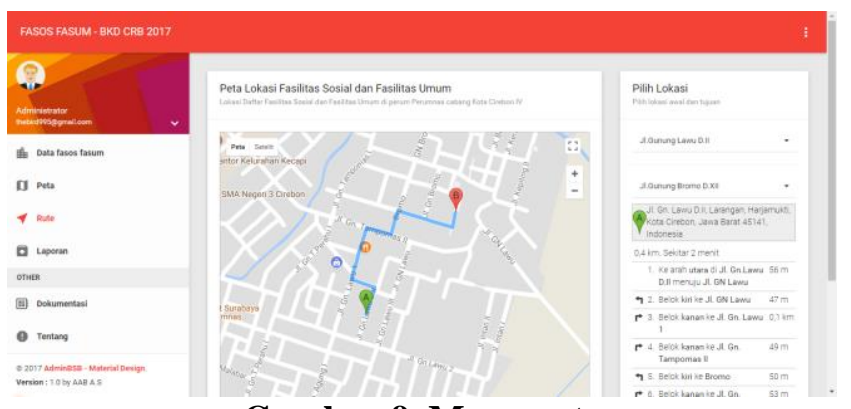

Gambar 9. Menu rute

\section{KESIMPULAN}

Dari hasil penelitian yang dimulai dari pokok permasalahan, analisis sistem sampai terbentuknya sebuah program aplikasi sistem informasi geografis pemetaan aset daerah dengnan menggunakan algoritme dijkstra, penulis dapat membuat kesimpulan bahwa sistem yang baru diharapkan dapat membantu proses pemetaan fasilitas sosial dan fasilitas umum karena pada sistem yang baru semua data terintegrasi dengan database.

Pada sistem yang baru pemetaan sudah menggunakan peta digital yaitu dengan peta dari API google Maps. Sistem yang baru lebih membantu dalam pemetaan fasilitas sosial dan 
fasilitas umum karena sudah menggunakan data keruangan untuk menentukan posisi/letak aset di lapangan, hal ini yang belum ada di sistem lama.

\section{SARAN}

Setelah dilakukannya penelitian ini, penulis mempunyai beberapa saran bahwa diharapkan untuk penelitian selanjutnya dapat membuat suatu sistem informasi geografis yang mampu memetakan seluruh fasilitas sosial dan fasilitas umum yang ada di Kota Cirebon. Selain itu aplikasi ini dapat terus dikembangkan dengan menambahkan halaman website untuk pengguna umum, sehingga aplikasi ini dapat diakses oleh siapa saja. Dalam sistem yang baru ini belum ada rute angkot, maka untuk pengembangan berikutnya diharapkan dapat ditambahkan rute angkot untuk menuju lokasi fasilitas sosial dan fasilitas umum.

\section{DAFTAR PUSTAKA}

[1] Fitria., Apri Triansyah. "Implementasi Algoritma Djikstra Dalam Aplikasi Untuk Menentukan Lintasan Terpendek Jalan Darat Antar Kota Di Sumatra Bagian Selatan." Jurnal Sistem Informasi (JSI) Vol 5 No.2 Oktober 2013 [online]. Available : https://ejournal.unsri.ac.id/index.php/jsi/article/view/840/430

[2] Iqbal., Mohammad., Gede Karya. "Sistem Informasi Geografis Fasilitas Umum dan Sosial Di Kabupaten Serang Menggunakan Mapserver dan MySQL Spasial." Prosiding Seminar Nasional Pendidikan Teknik Informatika (SENAPATI 2012) Singaraja Bali 22 September 2012 [online]. Available : https://id.scribd.com/document/369012059/prosiding2012-pdf

[3] Bachtiar., Adam Mukhairil., Rifky Efendi. Sistem Informasi Geografis Pemetaan Fasilitas Umum Di Kabupaten Sumedang Berbasis WEB. Jurnal Ilmiah Komputer dan Informatika (KOMPUTA) Vol 1 No 2 Bulan Oktober 2012 [online]. Available : http://komputa.if.unikom.ac.id/jurnal/sistem-informasi-geografis.k

[4] Ardana, dwi., Ragil Saputra. "Penerapan Algoritma Djikstra pada Aplikasi Pencarian Rute Bus Trans Semarang". Seminar Nasional Ilmu Komputer (SNIK 2016) Semarang 10 $\begin{array}{lcccc}\text { Oktober } & 2016 & \text { [online]. } & \text { Available } & \text { : } \\ \text { https://ilkom unnes ac.id/snik/prosiding/2016/45\%20SNIK } & \text { 334 Algoritma\%20Dijkstra.p }\end{array}$ $\underline{\mathrm{df}}$

[5] Fajri, Albes. Purwandari, EP. Coastera, FF. "Implementasi Sistem Informasi Geografis Untuk Pencarian Indekos Dengan Jarak Terpendek Menggunakan Metode Algoritma Djikstra”. Jurnal Rekursif Vo.6 No.1 Maret 2018 [Online]. Available : http://eprints.dinus.ac.id/12365/1/jurnal_12292.pdf

[6] Saido, AP. Suryoto. "Pemetaan Tanah Aset Pemerintah Kota Studi Kasus: Tanah Aset Pemerintah Kota Probolinggo". Konferensi Nasional Teknik Sipil 7 (KoNTekS 7 ) Universitas Sebelas Maret (UNS) Surakarta 24-26 Oktober 2013 [Online]. Available : https://sipil.ft.uns.ac.id/konteks7/prosiding/229K.pdf

[7] Taufik, muhammad. Anugraha AS. "Aplikasi Sistem Informasi Geografis Untuk Inventarisasi dan Evaluasi Aset Bangunan Milik Pemerintah Kota Surabaya (Studi Kasus: Surabaya Pusat)". Jurnal Geoid Vol.12 No.01 Agustus 2016 p.43-47 [Online]. Available : http://iptek.its.ac.id/index.php/geoid/article/download/2394/1961

[8] Rabiah, Sitti. "Penggunaan Metode Research And Development Dalam Penelitian Bahasa Indonesia di Perguruan Tinggi”. Seminar Nasional dan Launching Asosiasi Dosen Bahasa dan Sastra Indonesia (ADOBSI) 25 April 2015 [Online]. Available : https://osf.io/bzfsj/download/?format=pdf 
[9] Sunaryo, AH. Permanasari, Y. Harahap, E. "Pemilihan Rute Perjalanan Terpendek Menggunakan Algoritma Djikstra dan Google Map". Prosiding Matematika Vol.2 No.2 Tahun $2016 \quad$ [Online]. Available

http://karyailmiah.unisba.ac.id/index.php/matematika/article/view/4575/pdf

[10] Hendini, Ade. "Pemodelan UML Sistem Informasi Monitoring Penjualan dan Stok Barang (studi kasus distro zhezha pontianak". Jurnal Khatulistiwa Informatika Vol.IV No.2 Desember $2016 \quad$ [Online]. Available: https://ejournal.bsi.ac.id/ejurnal/index.php/khatulistiwa/article/download/1262/1027 